\title{
In Vitro Study of Disinfectant Used in Food Industry in Enterococcus sp
}

Luciana Furlaneto Maia (I), Naiele Muche (I), Márcia Regina Terra (I), Mayara Baptistucci Ogaki (II), Marly Sayuri Katsuda (I), Márcia Cristina Furlaneto (II)

(I) UTFPR - Universidade Tecnológica Federal do Paraná (Av dos Pioneiros 3131 Londrina PR), (II) UEL - Universidade Estadual de Londrina (Rodovia Celso Garcia Cid, Km 380, Londrina-PR)

\section{Resumo}

Representantes do gênero Enterococcus são membros da microbiota do trato gastrointestinal de homens e animais, encontrados também em alimentos, solo e água. Devido sua ampla distribuição as espécies E. faecium e E. faecalis são utilizados como bioindicadores de contaminação fecal e índice insatisfatório de saneamento. Além disso, estas tem sido relatadas em diversos episódios de infecções nosocomiais, com sérias dificuldades terapêuticas devido a ampla resistência a antimicrobianos. Sabe-se que alguns mecanismos gerais responsáveis pela resistência a antibióticos são também aplicáveis a biocidas de uso industrial. Em vista disso, este estudo propôs isolar Enterococcus sp da linha de produção de embutidos cozidos. Foram isolados um total de 40 colônias provenientes de 4 pontos de coleta. A coleta foi realizada com auxilio de um swab umedecido e friccionado na superfície do equipamento após a desinfecção. Posteriormente, foi semeado na superfície de agar KEA. As colônias características de Enterococcus foram identificadas por técnicas fenotípicas e confirmadas por técnicas moleculares (PCR). A sensibilidade microbiana aos sanitizantes foi realizada em placas de 96 poços, em experimentos distintos: inóculo+sanitizante+água e inóculo+sanitizante+BHI. Um total de $1 \times 108 \mathrm{UFC} / \mathrm{mL}$ de Enterococcus foi adicionado em cada poço acrescido dos sanitizantes hipoclorito, desinfetante ácido e dióxido de cloro, diluídos segundo as instruções do fabricante. As placas foram incubadas a $37^{\circ} \mathrm{C}$ e o

\footnotetext{
Referência:

Luciana Furlaneto Maia, Naiele Muche, Márcia Regina Terra, Mayara Baptistucci Ogaki, Marly Sayuri Katsuda, Márcia Cristina Furlaneto. In Vitro Study of Disinfectant Used in Food Industry in Enterococcus Sp. In: Anais do 12Congresso Latinoamericano de Microbiologia e Higiene de Alimentos - MICROAL 2014 [= Blucher Food Science Proceedings, num.1, vol.1]. São Paulo: Editora Blucher, 2014. DOI 10.5151/foodsci-microal-270
} 
desenvolvimento microbiano foi avaliado por densidade óptica nos tempos $0,15,30$ min e $1 \mathrm{~h}$ de incubação. Sessenta e sete porcento dos isolados foram confirmados para o gênero Enterococcus. Nos resultados de sensibilidade aos desinfetantes químicos, obtivemos que: pelo menos um isolado foi resistente a pelo menos um desinfetante em pelo menos um tempo de exposição; ou seja, os resultados foram variáveis em relação ao produto, tempo de exposição e presença ou não de matéria orgânica (BHI), indicando que a sensibilidade/resistencia é isolado-dependente.

Palavras-Chave: desinfetantes, resistencia, Enterococcus

Agência de Fomento: CNPq; Fundação ARAUCÁRIA 